\title{
Pulmonary Drug-metabolizing Enzyme in Alveolar Macrophages in Relation to Cigarette Smoking
}

\author{
Shosaku ABE, Shiro MAKIMURA, Shigeaki OGURA, \\ Isao NAKAJIMA and Yoshikazu KAWAKAMI
}

\begin{abstract}
We measured the aryl hydrocarbon hydroxylase (AHH) activity in alveolar macrophages (AMs) and the AHH inducibility in peripheral blood lymphocytes (PBLs) of 56 subjects with and without lung cancer.

There were no differences in the AHH inducibility in PBLs whether or not the host had lung cancer, regardless of a smoking history. The AHH activity in AMs in the current smoker group was significantly higher than in the non-smoker group. The AHH activity in AMs in the lung cancer group was higher than that in the non-lung cancer group, and the central-type group was significantly higher than the peripheraltype group.

These results suggest that the AHH activity in AMs is associated with the development of lung cancer and a history of cigarette smoking.
\end{abstract}

Key words: Aryl hydrocarbon hydroxylase, Lung cancer

Many carcinogens in tobacco smoke, such as polycyclic promatic hydrocarbons (PAH), are metabolized in mammalian cells to an ultimate carcinogenic form. Aryl hydrocarbon hydroxylase $(\mathrm{AHH})$ is a component of the microsomal mixed function oxygenase system located in the endoplasmic reticulum $(1,2)$, and is a pulmonary drugmetabolizing enzyme. AHH activity has been implicated as playing a role in carcinogenesis, teratogenesis and mutagenesis by $\mathrm{PAH}$. AHH is induced by several $\mathrm{PAH}$ and genetic variation in inducibility has been shown to influence tumorgenesis in mice (3). Kellermann et al (4) reported a significant correlation between the incidence of lung cancer and AHH inducibility in cultured human lymphocytes. Conversely, Paigen et al (5) reported a questionable relationship of the $\mathrm{AHH}$ inducibility to lung cancer risk.

The relationship between the lung cancer risk and AHH inducibility in human lymphocytes is still not conclusive. The aim of this study was to investigate whether differences of the AHH activity in alveolar macrophages (AMs), the primary target cell of $\mathrm{PAH}$, exist between lung cancer and non-lung cancer patients.

\section{SUBJECTS AND METHODS}

\section{Subjects}

Peripheral blood lymphocytes (PBLs) and AMs were obtained from 31 patients with lung cancer (24 males and 7 females) and from 25 subjects without lung cancer ( 20 males and 5 females). Patients with lung cancer had a mean age of 65 years (ranging from 23 to 78 years). The distribution of histologic type was 16 squamous cell carcinomas, 14 adenocarcinomas and 1 adenosquamous carcinoma. Patients included 16 current smokers, 6 ex-smokers and 9 non-smokers. The age of the non-lung cancer subjects ( 5 mediastinal benign tumors and 20 normal healthy volunteers) ranged from 22 to 69 , with a mean age of 50 years. Subjects included 11 smokers, 5 ex-smokers and 9 non-smokers. Individuals were classified as ex-smoker if they had stopped smoking for 3 months or more before this study.

From First Department of Medicine, School of Medicine, Hokkaido University, Sapporo

Received for publication November 28, 1989; Accepted for publication April 25, 1990

Reprint requests should be addressed to Shosaku Abe, MD, First Department of Medicine,

School of Medicine, Hokkaido University, North 15, West 7, Kita-ku, Sapporo 060, Japan 


\section{Culture of lymphocytes}

A $30 \mathrm{ml}$ sample of heparinized blood was withdrawn and used within 2 hours. PBLs were separated on Ficoll-Hypaque gradient solution, washed twice, resuspended $\left(10^{6}\right.$ cells $\left./ \mathrm{ml}\right)$ in about $30 \mathrm{ml}$ of RPMI-1640 medium containing $10 \%$ heatinactivated fetal calf serum and 1:100 dilution of pokeweed mitogen and phytohemagglutinin. Subsequently, the cell suspension was divided and poured into four Falcon T-30 flasks, and incubated in a $5 \% \mathrm{CO}_{2}$ humidified atmosphere at $37^{\circ} \mathrm{C}$ for two days. After two days, acetone containing $8 \mathrm{nmol}$ of the inducer 3-methylcholanthrene was added to two flasks, to yield a final concentration of $1.0 \mu \mathrm{M}$ in culture, and $5 \mu \mathrm{l}$ of acetone alone was added to the remaining two flasks. After incubation for an additional 24-hour period, the cells were harvested. These cells were immediately assayed for $\mathrm{AHH}$ inducibility.

\section{Preparation of $A M S$}

AMs were obtained during bronchoscopy from broncho-alveolar lavage fluid (BALF) mixed with $100-150 \mathrm{ml}$ of sterile saline through an Olympus BF-Type 10. AMs were separated by centrifugation of BALF, washed, and resuspended in $10-15 \mathrm{ml}$ of RPMI-1640 medium then centrifuged. AMs were purified to $90-95 \%$, and suspended in $1 \times 10^{6} / \mathrm{ml}$ solution. These cells were immediately assayed for AHH activity.

Enzyme assays

AHH activity was measured by Gurtoo et al's method (6). AHH activity is expressed as milliunits per $10^{6}$ cells, where one unit is the amount of fluorescence equivalent to the production of $1 \mathrm{pmol}$ per minute of 3-hydroxybenzo[a]pyrene.

\section{RESULTS}

We compared the AHH inducibility in PBLs and AHH activity in AMs from subjects with and without lung cancer. AHH activity in AMs in the lung cancer group was higher than that in the nonlung cancer group, but the difference was not statistically significant. There were no differences in AHH inducibility in PBLs among the two groups (Table 1). The relationship between the $\mathrm{AHH}$ activity in AMs and smoking history is given in Table 2. The AHH activity in AMs in the current smoker group $\left(2.5 \pm 1.7\right.$ units $/ \mathrm{min} / 10^{6}$ cells $)$ was

Table 1. AHH inducibility in PBLs and AHH activity in AMs in the lung cancer group and the non-lung cancer group.

\begin{tabular}{ccc}
\hline & $\begin{array}{c}\text { AHH activity in AMS } \\
\left(\mathrm{U} / \mathrm{min} / 10^{6} \text { cells }\right)\end{array}$ & AHH inducibility in PBLs \\
\hline $\begin{array}{c}\text { Lung cancer }(\mathrm{n}=31) \\
\text { Age: } 64.7 \pm 6.3\end{array}$ & $2.1 \pm 1.8$ & $1.1 \pm 0.2$ \\
$\begin{array}{c}\text { Non-lung cancer }(\mathrm{n}=25) \\
\text { Age: } 49.8 \pm 11.1\end{array}$ & $1.8 \pm 1.6$ & $1.1 \pm 0.3$ \\
\hline
\end{tabular}

Table 2. AHH inducibility in PBLs and $\mathrm{AHH}$ activity in AMs in patients with a smoking history.

\begin{tabular}{ccc}
\hline & $\begin{array}{c}\text { AHH activity in AMs } \\
\left(\mathrm{U} / \mathrm{min} / 10^{6} \text { cells }\right)\end{array}$ & AHH inducibility in PBLs \\
\hline $\begin{array}{c}\text { Current smoker }(\mathrm{n}=27) \\
\text { Age: } 57.3 \pm 9.4\end{array}$ & $2.5 \pm 1.7$ \\
$\begin{array}{c}\text { Ex-smoker }(\mathrm{n}=11) \\
\text { Age: } 57.6 \pm 9.4\end{array}$ & $2.2 \pm 1.1$ & $1.1 \pm 0.2$ \\
$\begin{array}{c}\text { Non-smoker }(\mathrm{n}=18) \\
\text { Age: } 57.2 \pm 6.4\end{array}$ & $1.1 \pm 0.2$ & $0.9 \pm 0.3$ \\
\hline
\end{tabular}


Table 3. AHH inducibility in PBLs and AHH activity in AMs in the lung cancer and non-lung cancer groups of current smokers.

\begin{tabular}{ccc}
\hline & $\begin{array}{l}\text { AHH activity in AMs } \\
\left(\mathrm{U} / \mathrm{min} / 10^{6} \text { cells }\right)\end{array}$ & AHH inducibility in PBLs \\
\hline $\begin{array}{c}\text { Lung cancer } \\
\text { smoker }(\mathrm{n}=16) \\
\text { Age: } 64.6 \pm 6.8\end{array}$ & $2.5 \pm 1.6$ & $1.1 \pm 0.2$ \\
$\begin{array}{c}\text { Non-lung cancer } \\
\text { smoker }(\mathrm{n}=11) \\
\text { Age: } 50.0 \pm 12.1\end{array}$ & $2.6 \pm 1.9$ & $1.2 \pm 0.2$ \\
\hline
\end{tabular}

Table 4. AHH activity in AMs in the central-type and the peripheral-type groups of squamous cell carcinomas.

\begin{tabular}{lc}
\hline & $\begin{array}{l}\text { AHH activity in AMs } \\
\left(\mathrm{U} / \mathrm{min} / 10^{6} \text { cells }\right)\end{array}$ \\
\hline Central-type $(\mathrm{n}=5)$ & $4.6 \pm 1.8 \quad \neg \quad \mathrm{p}<0.001$ \\
Peripheral-type $(\mathrm{n}=11)$ & $1.6 \pm 1.3 \quad \mathrm{~J}$ \\
\hline
\end{tabular}

significantly higher than that in the non-smoker group $\left(1.1 \pm 0.2 \mathrm{U} / \mathrm{min} / 10^{6}\right.$ cells $)(\mathrm{p}<0.005)$. No significant differences were observed among the current smoker, ex-smoker and non-smoker groups in the $\mathrm{AHH}$ inducibility in PBLs. There was no difference in $\mathrm{AHH}$ inducibility or $\mathrm{AHH}$ activity among the smoker groups with and without lung cancer. The mean age of the current smoker group without lung cancer was about 15 years younger than that of the lung cancer group (Table 3).

The relationship between the $\mathrm{AHH}$ activity in AMs of the patients with the central-type of squamous cell carcinoma and the peripheral-type group is shown in Table 4. The AHH activity of the central-type group $\left(4.6 \pm 1.8 \mathrm{U} / \mathrm{min} / 10^{6}\right.$ cells) was significantly higher than that of the peripheral-type group $\left(1.6 \pm 1.3 \mathrm{U} / \mathrm{min} / 10^{6}\right.$ cells $)(p<0.001)$.

\section{DISCUSSION}

In this study, there were no differences in the AHH inducibility in PBLs between the lung cancer and non-lung cancer groups and regardless of a smoking history. Our results do not support the observation of Kellermann et al (4) who reported a significant correlation between the incidence of lung cancer, smoking history and AHH inducibility in PBLs. The AHH activity in AMs was significantly higher in the current smoker group than that in the non-smoker group. Thus, a smoking history seems to induce AHH activity in AMs. However, the AHH activity in AMs of the ex-smoker group was the same that of the current smoker group. Cantrell et al (7) reported that AHH activity in AMs initially increases and afterwards slowly decreases to control levels by about 2 months after cessation of smoking. It is not known, however, whether or not these changes occur in AMs of smokers chronically exposed to cigarette smoke over an extended period of time. Our results indicate that there would be a very slow decrease in the AHH activity of AMs.

There was no difference in the $\mathrm{AHH}$ activity in AMs when comparing the current smoker group with and without lung cancer, but the mean age of the current smoker group without lung cancer was about 15 years younger. One possible explanation is that the current smoker group without lung cancer had not yet arrived at the onset age for developing lung cancer. They might develop lung cancer as they 
grow older. It has previously been reported that variations in the level of pulmonary drug-metabolizing enzyme activity exist according to age and season of measurement $(6,8)$. The AHH inducibility in PBLs tends to decrease with increasing age. In our studies, although the lung cancer group was significantly older than the non-lung cancer group, the AHH activity in AMs of the lung cancer group was higher than that in the non-lung cancer group.

Previous studies have shown a strong relationship between smoking history and lung cancer risk, especially in the central-type of squamous cell carcinoma and small cell carcinoma $(9,10)$. It is interesting that the AHH activity in AMs of the patients with the central-type of squamous cell carcinoma was higher than that of the peripheral-type. In this study, the patients with squamous cell carcinoma are all heavy smokers, and their smoking index was the same as that of the patients with peripheral-type.

The genetics of the $\mathrm{AHH}$ induction in mice varies by species (11), but in humans it has not been determined whether it is a monogenic or a polygenic $\mathrm{Ah}$ locus (12). However, our studies demonstrate that the $\mathrm{AHH}$ activity in AMs may be determined genetically, so that lung cancer, especially centraltype squamous cell carcinoma, may develop from cigarette smoking along with other factors.

Thus, further research on $\mathrm{AHH}$ activity using AMs should help to more correctly define its association with the development of lung cancer and cigarette smoking. Finding such a relationship would be a step toward the identification of a high risk group, early detection and decreased mortality from lung cancer.

\section{REFERENCES}

1) Nebert DW, Gelboin HV. Substrate-inducible microsomal aryl hydroxylase in mammalian cell culture I. Assay and properties of induced enzyme. J Biol Chem 243: $6242,1968$.

2) Nebert DW, Gelboin HV. Substrate-inducible microsomal aryl hydroxylase in mammalian cell culture II. Cellular responses during enzyme induction. J Biol Chem 243: 6250, 1968.

3) Benedict WF, Considine N, Nevert DW. Genetic differences in aryl hydrocarbon hydroxylase induction and benzo(a)pyrene-produced tumorgenesis in the mouse. Mol Pharmacol 6: 266, 1973.

4) Kellermann G, Shaw CR, Kellermann ML. Aryl hydrocarbon hydroxylase inducibility and bronchogenic carcinoma. N Engl J Med 289: 934, 1973.

5) Paigen B, Gurtoo HL, Minowada J, et al. Questionable relation of aryl hydrocarbon hydroxylase to lung-cancer risk. N Engl J Med 297: 346, 1977.

6) Gurtoo HL, Minowada J, Paigen B, Parker NB, Hayner NT. Factors influencing the measurement and the reproducibility of aryl hydrocarbon hydroxylase activity in cultured human lymphocytes. J Natl Cancer Inst 59: 787, 1977.

7) Cantrell ET, Warr GA, Busbee DL, Martin RR. Induction of aryl hydrocarbon hydroxylase in human pulmonary alveolar macrophages by cigarette smoking. J Clin Invest 52: 1881, 1973.

8) Paigen B, Minowada J, Gurtoo HL, Hayner NT. Distribution of aryl hydrocarbon hydroxylase inducibility in cultured human lymphocytes. Cancer Res 37: 1829, 1977.

9) Wynder EL, Graham EA. Tobacco smoking as a possible etiologic factor in bronchogenic carcinoma. JAMA 143: 329, 1950.

10) Kreyberg L. The significance of histological typing of the epidemiology of primary epithelial lung tumor: A study of 466 cases. Br J Cancer 8: 199, 1954.

11) Thomas PE, Kouri RE, Hutton J. The genetics of aryl hydrocarbon hydroxylase induction in mice: A single gene difference between $\mathrm{C} 57 \mathrm{BL} / 6 \mathrm{~J}$ and $\mathrm{DBA} / 2 \mathrm{~J}$. Biochem Genet 6: 157, 1972.

12) Barsch H, Armstrong B. Carcinogen-metabolizing enzymes and susceptibility to chemical carcinogenesis: Host factors in human carcinogenesis. IARC, Lyon, 1982 , p.337. 